\title{
Impacts of Strategic Mobility Restrictions Policies during 2020 COVID-19 Outbreak on Brazil's Regional Air Quality
}

Special Issue:

Special Issue on Air Quality in a Changed World: Regional, Ambient, and Indoor Air Concentrations from the COVID to Post-COVID Era (IV)

\section{OPEN ACCESS}

Received: November 30, 2021 Revised: February 4, 2022 Accepted: March 3, 2022

\section{${ }^{*}$ Corresponding Author:} taciana@desa.ufmg.br

\section{Publisher:}

Taiwan Association for Aerosol Research

ISSN: $1680-8584$ print ISSN: 2071-1409 online

(c) Copyright: The Author(s). This is an open access article distributed under the terms of the Creative Commons Attribution License (CC BY 4.0), which permits unrestricted use, distribution, and reproduction in any medium, provided the original author and source are cited.

\section{Anderson P. Rudke ${ }^{1,2}$, Daniela S. de Almeida ${ }^{3}$, Ronaldo A. Alves ${ }^{2}$, Alexandra Beal' ${ }^{2}$, Leila D. Martins ${ }^{2}$, Jorge A. Martins ${ }^{2}$, Ricardo Hallak ${ }^{4}$, Taciana T. de Almeida Albuquerque ${ }^{1,5^{*}}$}

\author{
${ }^{1}$ Universidade Federal de Minas Gerais, Belo Horizonte - MG, 31270-901, Brazil \\ ${ }^{2}$ Federal University of Technology - Paraná, Londrina - PR, 86047-125, Brazil \\ ${ }^{3}$ Federal University of São Carlos, São Carlos - SP, 13565-905, Brazil \\ ${ }^{4}$ Instituto de Astronomia, Geofísica e Ciências Atmosféricas, Universidade de São Paulo, São \\ Paulo - SP, 05508-090, Brazil \\ ${ }^{5}$ Post Graduation Program on Environmental Engineering, Federal University of Espírito Santo, \\ Vitória - ES, 29075-910, Brazil
}

\section{ABSTRACT}

With the unexpected arrival of the COVID-19 pandemic, countries worldwide were forced to take measures to curb its transmission. Mobility restrictions policies were the primary preventive measures applied around the globe. In addition to reducing the disease spread, they resulted in air quality changes in urbanized areas. In this sense, this study aimed to investigate how the mobility restrictions imposed by public policies impacted the air quality in Brazil during the COVID-19 2020 outbreak. Therefore, air quality (CO, $\mathrm{NO}_{2}, \mathrm{PM}_{10}, \mathrm{PM}_{2.5}$, and $\mathrm{O}_{3}$ ) and urban mobility datasets available in five populous Brazilian states (São Paulo, Rio de Janeiro, Espírito Santo, Paraná, and Rio Grande do Sul) were analyzed. Variations in air pollutant concentrations were verified by comparing the period during mobility restrictions (2020) and the average concentrations found before the restrictions (2015-2019). In addition, spatial assessment of changes was evaluated using tropospheric $\mathrm{NO}_{2}$ column densities from the TROPOMI. Although there was no national regulation regarding mobility restrictions, the results show that the reduction in urban mobility was similar for all the analyzed states. Following the mobility behavior, reducing air pollutant concentrations were significant for the first 30 days of restrictions. During this period, the most substantial reductions were observed for $\mathrm{CO}$ in the State of Rio Grande do Sul $(-53 \%), \mathrm{NO}_{2}$ in Rio de Janeiro $(-34 \%)$, and $\mathrm{PM}_{10}$ in Espírito Santo $(-23 \%)$. The exception was observed for $\mathrm{O}_{3}$, which followed the world trend of increasing concentrations (e.g., $40 \%$ increase in Paraná). Spatially, it was possible to evidence that large urban centers (with a large vehicle fleet) were the ones that showed the most significant reduction in $\mathrm{NO}_{2}$. However, when analyzing longer periods (over 90 days), there is a trend towards an increase in the concentrations of primary pollutants and a consequent reduction in $\mathrm{O}_{3}$, reflecting the significant increase in mobility rates.

Keywords: Air pollution, Lockdown, Coronavirus, Brazilian policies

\section{INTRODUCTION}

Currently, global society faces the most significant health and humanitarian crisis in its recent history: The COVID-19 pandemic, caused by the SARS-CoV-2 virus (Pak et al., 2020; The Lancet, 2020). The high transmission potential of this virus through the air and via personal contact soon demanded a global alert, mainly to prevent the spread of the virus (Fan et al., 2020), since the advance of the disease was accompanied by a concomitant crisis in the health systems (Blumenthal et al., 2020; 
de Oliveira Andrade, 2020). Thus, most governments worldwide adopted policies such as keeping a safe distance, wearing masks, using alcohol-based products to disinfect hands, staying home, and banning social and public events. In this context of preventive measures, mobility restrictions proved to be very effective in containing the transmission of the virus (Martins et al., 2020; Wang et al., 2020). In addition, they resulted in a reduction in air pollution in several regions (Bauwens et al., 2020; Chossière et al., 2021; He et al., 2021; Morales-Solís et al., 2021; Rana et al., 2021; Zambrano-Monserrate et al., 2020).

The reduction of air pollution levels, due to a decrease in mobility, has proven to be an "openair laboratory" and, as a consequence, has been experimentally investigated by several academic studies (e.g., Bao and Zhang, 2020; Bauwens et al., 2020; Collivignarelli et al., 2020; Dutheil et al., 2020; Liu et al., 2021; Lokhandwala and Gautam, 2020; Sharma et al., 2020; Xu et al., 2020). These studies have shown that the levels of urban pollution reduction are essentially related to local economic vocation and the degree of restrictions imposed on social distancing (Chossière et al., 2021). Thus, while several locations showed significant improvements in air quality during the pandemic (Bao and Zhang, 2020; Dutheil et al., 2020; Lokhandwala and Gautam, 2020; Mishra and Kulshrestha, 2021), others presented a positive correlation between the increase in the number of cases of COVID-19 and the high levels of pollution (Conticini et al., 2020; Travaglio et al., 2021).

In Brazil, several studies have been carried out to understand the effects of the pandemic on air quality (Bainy et al., 2021; Dantas et al., 2020; Mantovani et al., 2021; Rocha et al., 2021; Silva Júnior et al., 2020). These surveys are mainly concentrated in the Southeast region of Brazil, especially in the metropolitan areas of São Paulo and Rio de Janeiro (Debone et al., 2020; Krecl et al., 2020; Nakada and Urban, 2020). Some of these studies found that, in general, there was an increase in concentrations of pollutants in more industrialized regions. In contrast, there was a reduction in air pollutants in areas with a large fleet of vehicles (Nakada and Urban, 2020; Rudke et al., 2021).

At the moment of writing this text, Brazil is the second country most affected by the pandemic, counting about 25 million cases and more than 625 thousand deaths (MS, 2022). There was no clear position in favor of lockdown or mobility restrictions at the federal level, even with the worsening of the health crisis and the high number of contamination and deaths. The governors of each State were left to arbitrate on local control policies (Barberia e Gómez, 2020; Boschiero et al., 2021; Russo Rafael et al., 2020; Touchton et al., 2021), revealing different scenarios of mobility restrictions. Overall, the adoption of tighter restrictions positively impacted the health system (Alfano and Ercolano, 2020; Lau et al., 2021; Meo et al., 2020; Wilder-Smith et al., 2021). With a very variable range of restrictive measures, quite different from other countries, this scenario offers a unique opportunity to understand the impact of such measures on air pollution. In this sense, this study aimed to evaluate the impact of the mobility restrictions implemented during the 2020 COVID-19 outbreak on the regional air quality of five Brazilian States (São Paulo, Rio de Janeiro, Espírito Santo, Paraná, and Rio Grande do Sul; distributed in the most densely populated regions of the country - Southeast and South). In more specific terms, this study sought to assess how mobility restrictions affected the concentrations of air pollutants at different time intervals and how these changes are spatially distributed.

\section{METHODS}

\subsection{Study Area}

Brazil is the country with the largest territory in South America, with an area of about 8.5 million $\mathrm{km}^{2}$ (IBGE, 2020). The country borders to the west with most countries of the continent and, to the east, with the Atlantic Ocean (Fig. 1). The country is geographically divided into 27 federative units (twenty-six States and the Federal District) and has an estimated population of more than 210 million inhabitants (IBGE, 2021), with a population density of 22.43 inhabitants per $\mathrm{km}^{2}$. The Southeast and South Regions are the most densely populated, followed by the Northeast, Central-west, and North (IBGE, 2020). The South, Southeast, and Central-west Regions have the most extensive agricultural and livestock activities areas. The largest area of forests remnants is concentrated in the northern part of the country, mainly due to the Amazon rainforest. Besides, the Southeast Region is the most industrialized area in the country, with São Paulo being 

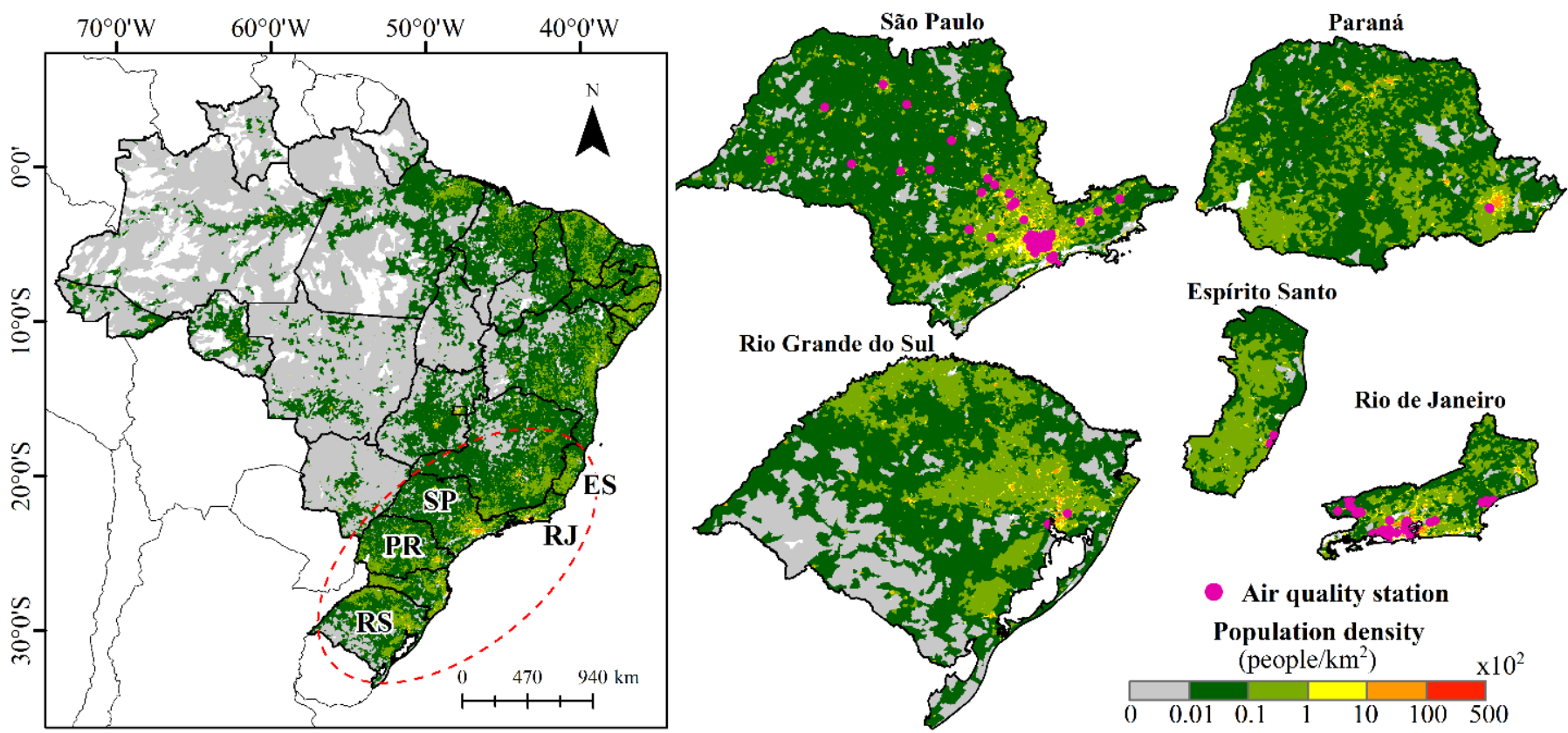

- Air quality station

Population density

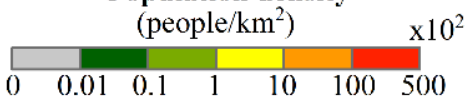

Fig. 1. Study area and distribution of the air quality monitoring stations by state. SP: São Paulo, PR: Paraná; RS: Rio Gramde do Sul; ES: Espírito Santo; RJ: Rio de Janeiro. The red dashed ellipse highlights the South and Southeast Regions of Brazil.

the State with the most prominent industrial production (Nakazato et al., 2015; Vieira-Filho et al., 2015).

Stationary sources play a fundamental role in the air pollutants levels in Brazil (Kawashima et al., 2020); however, mobile sources are the primary sources of air pollution in large urban centers (Almeida et al., 2018; Andrade et al., 2012, 2017; Moreira et al., 2018; Rudke et al., 2021). The country has a fleet of more than 106 million vehicles - considering light and heavy-duty vehicles (DENATRAN, 2020). There are a few air pollution inventories in the country, mostly restricted to vehicular emissions and some urban areas (Andrade et al., 2017; Carvalho et al., 2015; Rafee et al., 2017; Réquia et al., 2015; Souza et al., 2013; Tsao et al., 2012). In Brazil, most vehicles are powered by diesel, gasoline (gasoline + ethanol), and ethanol. The first use of ethanol as fuel was in the 1920-1930s (adding ethanol to gasoline). In Brazil, it has been used since the 1970s (blended and pure), and later also the use of ethanol in the flex-fuel vehicles resulted in the reduction of some atmospheric pollutants (Brito et al., 2018; Salvo et al., 2017). However, biofuels can have more significant impacts on regional climate forcings and human health than previously thought (Tsao et al., 2012).

This study focuses on the South and Southeast Regions of Brazil, more specifically the examined data correspond to São Paulo (SP), Paraná (PR), Espírito Santo (ES), Rio de Janeiro (RJ), and Rio Grande do Sul (RS) States (Fig. 1). Together, these five States account for approximately $42.8 \%$ of the Brazilian population (IBGE, 2021) and encompass the largest metropolises in the country, such as São Paulo and Rio de Janeiro, which gather the most significant vehicle fleets (DENATRAN, 2020). With the increase in vehicular emissions and few works aimed at reducing air pollution for Brazil, the analysis of the air pollutants levels is a significant contribution to the country.

\subsection{Datasets}

\subsubsection{Ground-based data}

The air quality data used in this study was obtained through the Institute of Energy and Environment (in Portuguese Instituto de Energia e Meio Ambiente - IEMA; http://energiaeambiente. org.br/qualidadedoar). The IEMA is a Brazilian Non-profit Organization that integrates, organizes, analyses, and makes available air quality monitoring data carried out in Brazil. The IEMA air quality platform currently provides monitoring data from 2000 onwards for ten States and the Federal District.

Given the need for data available for 2020 , only monitoring stations that had measurements 
carried out for this year were considered. Another criterion used to select stations was the need for at least 50\% of the data available between 2015 and 2019. Based on these criteria, 97 automatic air quality stations, available in the same five Brazilian States, were selected for the evaluations carried out in this research (Fig. 1). The IEMA data for these monitoring stations were obtained from the State Environmental Institute of Espírito Santo (IEMA-ES), Water and Land Institute (IAT) of the State of Paraná, State Environmental Institute (INEA) of Rio de Janeiro, Environmental Protection Foundation (FEPAM) of Rio Grande do Sul State and, Environmental Company of the State of São Paulo (CETESB). The selected stations are capable of monitoring ground-based concentrations of carbon monoxide ( $\mathrm{CO}-41$ stations), ozone $\left(\mathrm{O}_{3}-75\right.$ stations), particulate matter ( $\mathrm{PM}_{10}-73$ stations; $\mathrm{PM}_{2.5}-17$ stations), and nitrogen dioxide $\left(\mathrm{NO}_{2}-53\right.$ stations). More information about the stations used is available in Table S1 (Supplementary Material).

\subsubsection{Satellite data}

As air pollutant ground-level concentrations are only available for sites with monitoring stations, Tropospheric $\mathrm{NO}_{2}$ column densities measured by the TROPOspheric Monitoring Instrument (TROPOMI) were used to verify the spatial trend variations in air quality. The TROPOMI sensor is coupled to the Sentinel-5 Precursor (S-5P) satellite. The Tropospheric $\mathrm{NO}_{2}$ column density dataset has about $2600 \mathrm{~km}$ of swath width, resulting in almost daily global coverage (equator crossing time at 13:30 LT) (Veefkind et al., 2012). The Tropospheric $\mathrm{NO}_{2}$ column densities data from TROPOMI showed promising results compared to measurements carried out on the ground (Verhoelst et al., 2021). Furthermore, the data has demonstrated excellent correlations with ground-based $\mathrm{NO}_{2}$ concentrations acquired from air quality monitoring stations (e.g., Bassani et al., 2021; Cersosimo et al., 2020; Kim et al., 2021; Virta et al., 2021).

As Tropospheric $\mathrm{NO}_{2}$ column densities are not available for the entire study period (data available since the end of April 2018), only data from 2019 and 2020 were used in the analyses. The Level 2 OFFL version product was adopted in this study, with a spatial resolution of $5.5 \times 3.5 \mathrm{~km}^{2}$ at the nadir. These data were statistically processed and downloaded from the Google Earth Engine platform. During the analysis, only $\mathrm{NO}_{2}$ information with a quality assurance value (greater than 0.75 ) was used, following the guidelines recommended by the producers (Eskes et al., 2019).

\subsubsection{COVID-19 cases and mobility data}

Data from the Google Community Mobility Reports were analyzed to assess the mobility restrictions policies adopted by the Brazilian States during the COVID-19 pandemic. The data is freely available (https://www.google.com/covid19/mobility/) and contains anonymous information on movement trends obtained from smartphone users during their travels. The platform provides movement trend information for the categories "Grocery \& pharmacy", "Parks", "Transit stations", "Retail \& recreation", "Residential" and, "Workplaces". To demonstrate variations during the analyzed period, we adopted the "Transit stations" class that presents the mobility trends for public transport hubs (e.g., subway, bus, and train stations), as this would be the class most impacted by public policies aimed at social distancing. According to the producers, the daily percentage changes are calculated based on the reference day, which is the median value of the five weeks between $3^{\text {rd }}$ January and $6^{\text {th }}$ February 2020.

Daily data on new confirmed cases of COVID-19 were obtained through the dissemination platform of the Brazilian Ministry of Health (https://covid.saude.gov.br/). The platform disseminates the information that is collected at the municipal and State levels. As the analyzed States have very different number and spatial distribution of populations, it was decided to normalize the data of new cases of COVID-19 according to the number of inhabitants in each State. Thus, the information used was daily confirmed new cases per 100 thousand people.

\subsubsection{Synoptic conditions}

It is known that meteorological conditions substantially impact air pollutants levels; precipitation, for example, plays an important role in removing air pollutants from the atmosphere. Therefore, to assess the variation in the behavior of pollutant concentrations caused by mobility restrictions in Brazil during the COVID-19 pandemic, it is essential to check the meteorological conditions, as demonstrated by Rudke et al. (2021). 
The synoptic conditions were verified considering the European Center for Medium-Range Weather Forecasts (ECMWF) Reanalysis version 5 (ERA5) (Hersbach et al., 2020) (available in https://www.ecmwf.int/en/forecasts/dataset/ecmwf-reanalysis-v5). The ERA5 reanalysis provides hourly data and covers the globe on a $30 \mathrm{~km}$ horizontal grid. In this latest release, the atmosphere is resolved using 137 levels from the surface up to a height of $80 \mathrm{~km}$, capturing finer details of atmospheric phenomena (Hersbach et al., 2020).

Based on the hourly Convective Available Potential Energy (CAPE) and Precipitable Water (PWater) from ERA5, it was evaluated whether there were significant differences in meteorological conditions for the first semester of 2020 in comparison with the same period for 2019. In this case, the Student T-test was the statistical method used for testing the hypothesis, considering a confidence level of $95 \%(\alpha=0.05)$.

\section{RESULTS AND DISCUSSION}

\subsection{Synoptic Conditions}

Student's t-test results analysis demonstrates that, in general, the energy available for deep convection and moisture was statistically different between the first semester of 2019 compared to 2020 (CAPE: t-value - 25.0 and p-value - <0.01; PWater: $t$-value - 2.3 and $p$-value - 0.02). Higher CAPE and Pwater values were observed for 2019 (see Fig. S1, Supplementary Material). Therefore, it can be inferred that the prevailing atmospheric conditions in 2019 were more prone to mixing the atmospheric mass than in 2020. Thus, it is possible to conclude that during the first semester of 2019, there was a higher dissipation of pollutants caused by meteorological effects when compared to 2020. This fact was also observed by Rudke et al. (2021) in a study carried out for the State of São Paulo. The authors indicated that the greater volume of rainfall in 2019, when compared to 2020, prevented the observation of significant reductions in air pollutant concentrations during the period of restrictions caused by the COVID-19 outbreak. Consequently, the analysis of expected decreases in the concentration of air pollutants must consider the differences observed for the atmospheric conditions acting in the period before and during the COVID-19 pandemic.

\subsection{Changes Observed in Air Quality and Mobility}

To assess changes in air pollutant concentrations, the comparison between observed values for 2020 and the five years before the pandemic (2015-2019) was considered. The interval between 2015-2019 was supposed to minimize interannual variations, which occur even in years without a pandemic, mainly due to atmospheric conditions and economic factors. Thus, hereafter these periods will be compared to demonstrate the impact of mobility restrictions due to the COVID-19 outbreak on air pollutant concentrations observed for Brazil. In this sense, Fig. 2. presents 13-day centralized moving averages for the evaluated pollutants (CO, NO $2, \mathrm{PM}_{10}$, and $\mathrm{O}_{3} ; \mathrm{PM}_{2.5}$ data for the States of São Paulo and Rio de Janeiro are available in Fig. S2). The figure also shows the mobility trend observed during the pandemic and information regarding new confirmed cases of COVID-19.

According to Fig. 2, it is noted that, in general, even before the first mobility restrictions adopted in Brazil ( $1^{\text {st }}$ January-15 $5^{\text {th }}$ March), below-average concentrations (2015-2019) were found for 2020. The precipitation regime observed for 2020 can partially explain this fact since it was generally higher than the average from 2015 to 2019 (Fig. S3), except for Paraná and Rio Grande do Sul, which had lower rainfall for 2020. Atypical weather conditions were observed by Martins et al. (2020), with rainfall above average in North and Northeastern Brazil (e.g., $446.3 \mathrm{~mm}$ for March in Manaus-MA, which is about $50 \%$ higher than the expected rainfall for the month) and drier and warmer atmospheric conditions in Sothern Brazil (e.g., $13.8 \mathrm{~mm}$ for March in Curitiba$P R$, while the expected is $125 \mathrm{~mm}$ ).

During the suspension of in-person activities decreed by the States, which started on $16^{\text {th }}$ March 2020 for practically all Brazilian States (Dantas et al., 2020; Geraldi et al., 2021; Rudke et al., 2021), there was a sharp reduction in most pollutants for most States, following the mobility behavior. These more accentuated reductions are mainly observed in the States of São Paulo and Rio de Janeiro, where the behavior of air pollutants directly followed the initial changes in mobility. It occurs because most of its monitoring stations are located in their metropolitan areas, where 

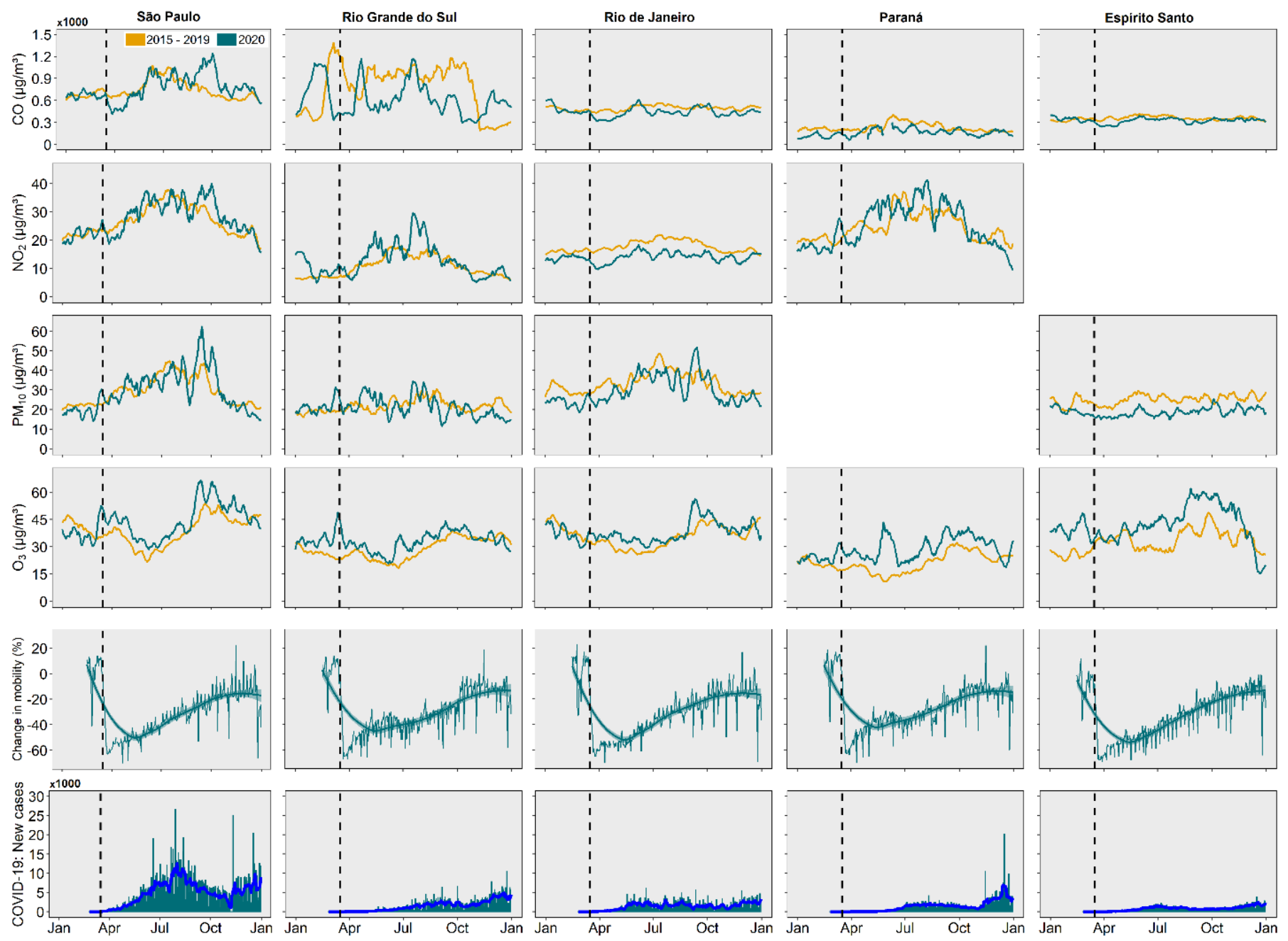

Fig. 2. 13-day centralized moving averages considering air pollutants concentration before (yellow) and during (green) the COVID-19 pandemic; percentage in mobility change (in blue patterns in-transit movements); and daily trends in the number of new confirmed cases of COVID-19 in Brazil (in blue line are the weekly moving averages), separated by five States. The dashed line indicates the date $16^{\text {th }}$ March 2020, representing the beginning of Brazil's mobility restrictions.

vehicular traffic dominates the source of outdoor air pollution (Carvalho et al., 2015; Dantas et al., 2020), differently, for example, from Paraná, where the available stations are located in an industrial area.

In agreement with the state information portals on COVID-19, during 2020, there were still some mobility policies that were even more restrictive, as in the case of the States of São Paulo and Paraná, which during some holidays even closed essential services and stipulated prohibition of displacement during the night period. It is important to emphasize that in 2020 in Brazil, unlike in other countries, there was no measure of strict mobility restrictions as the lockdown. In 2021, the city of Araraquara (in upstate São Paulo) was the first one in Brazil to use such a measure, which proved to be quite effective (Figueiredo Filho and de Oliveira Silva, 2021; Malta et al., 2021), once it reduced the number of deaths in the city up to $80 \%$ (Francisco et al., 2021).

In all the five States studied, the concentration of $\mathrm{O}_{3}$ was higher in 2020 than the average from 2015 to 2019. This increase has also been observed worldwide and may be related to the chemical formation regime of $\mathrm{O}_{3}$ (Collivignarelli et al., 2020; Dutta and Jinsart, 2021; Gao et al., 2021; Grange et al., 2021; Lu et al., 2013; Sharma et al., 2020; Sicard et al., 2020), which in large cities is usually Volatile Organic Compounds (VOC) limited. According to Siciliano et al. (2020), who evaluated the increase of $\mathrm{O}_{3}$ in Rio de Janeiro city, the greatest concentrations result from higher ratios of non-methane hydrocarbons $(\mathrm{NMHC})$ and nitrogen oxides $\left(\mathrm{NO}_{\mathrm{x}}\right)$, i.e., more significant reduction of $\mathrm{NO}_{x}$ than of $\mathrm{NMHC}$. 
In general, during 2020, the measures imposed by the State governments were similar between all of them: Restricting social events, regulating the occupation of people in shops, restaurants, gyms, as well as adopting teleworking for administrative services, and remote classes, among several other measures of restriction or total prohibition to avoid or reduce agglomerations of people. However, the intensity of measures and the commitment of the population were variable (Fig. 2). This occurred due to measures of "relaxation" of the mobility restriction policies adopted by the State governments along the time, in addition to the mismatch between the federal, State, and municipal spheres, which generated uncertainties in the population, favoring the reduction of social distancing. During this period, many closed shops were reopened (with reduced opening hours), which significantly increased the flow of people in large urban centers. This fact induced an increase in mobility and consequently in air pollutants concentrations, generating substantial growth in the number of new cases of COVID-19, which first peaked in mid-July to September (Fig. 2). Besides that, during the pandemic, some industrial activities were intensified, increasing concentrations of $\mathrm{NO}_{x}, \mathrm{SO}_{2}, \mathrm{CO}_{2}$, and $\mathrm{CO}$ (Nakada and Urban, 2020; Rudke et al., 2021).

Table 1 presents the relative differences (\%) for air pollutants and mobility in different time intervals (extended version of the table can be accessed in the supplementary material - Table S2). It is seen that the most significant reductions in primary pollutants $\left(\mathrm{NO}_{2}\right.$ and $\left.\mathrm{CO}\right)$ and $\mathrm{PM}$ are kept for shorter time intervals, where the mobility restrictions policies were more stringent. On the other hand, when more extended periods are observed, it is possible to perceive a smaller impact of mobility restrictions on the concentrations of these pollutants.

Through Table 1, it is observed a sharp reduction in mobility for the first 15 days of mobility restrictions. However, the highest mobility reduction was reached for all the States about 30 days after the first restrictive measure (reduction of approximately $50 \%$ ); the same behavior was observed for most of the air pollutants. Looking at the results of restrictions for social distancing applied globally, only in some cases was there a reduction immediately after the measure was enacted, e.g., in India, China, Switzerland, and the Netherlands (Venter et al., 2020).

During the first 15 days, the pollutants concentrations at all States decreased, even the secondary pollutants- $-\mathrm{O}_{3}$ and $\mathrm{PM}_{2.5}$. This fact must be associated with the atmospheric conditions

Table 1. Relative differences (\%) in air pollutant concentrations and mobility averaged for the five Brazilian States analyzed.

\begin{tabular}{|c|c|c|c|c|c|c|c|c|c|c|c|}
\hline & \multirow{2}{*}{ Pollutant } & \multicolumn{2}{|c|}{15 days } & \multicolumn{2}{|c|}{30 days } & \multicolumn{2}{|c|}{90 days } & \multicolumn{2}{|c|}{180 days } & \multicolumn{2}{|c|}{290 days } \\
\hline & & Conc. & Mobility & Conc. & Mobility & Conc. & Mobility & Conc. & Mobility & Conc. & Mobility \\
\hline \multirow[t]{3}{*}{ ES } & $\mathrm{CO}$ & $-18.8 \%$ & $-52.3 \%$ & $-24.4 \%$ & $-56.9 \%$ & $-17.2 \%$ & $-54.7 \%$ & $-14.0 \%$ & $-33.5 \%$ & $-10.5 \%$ & $-35.1 \%$ \\
\hline & $\mathrm{PM}_{10}$ & $-21.6 \%$ & & $-23.3 \%$ & & $-28.4 \%$ & & $-28.9 \%$ & & $-26.4 \%$ & \\
\hline & $\mathrm{O}_{3}$ & $-9.6 \%$ & & $5.1 \%$ & & $11.3 \%$ & & $27.5 \%$ & & $24.3 \%$ & \\
\hline \multirow[t]{3}{*}{ PR } & $\mathrm{CO}$ & $-41.1 \%$ & $-44.9 \%$ & $-45.1 \%$ & $-48.9 \%$ & $-29.5 \%$ & $-42.5 \%$ & $-30.6 \%$ & $-37.6 \%$ & $-27.1 \%$ & $-29.1 \%$ \\
\hline & $\mathrm{NO}_{2}$ & $-5.0 \%$ & & $-16.6 \%$ & & $8.1 \%$ & & $7.2 \%$ & & $4.7 \%$ & \\
\hline & $\mathrm{O}_{3}$ & $-46.0 \%$ & & $43.9 \%$ & & $74.7 \%$ & & $57.1 \%$ & & $40.1 \%$ & \\
\hline \multirow[t]{5}{*}{ RJ } & $\mathrm{CO}$ & $-16.5 \%$ & $-51.3 \%$ & $-22.6 \%$ & $-54.2 \%$ & $-12.2 \%$ & $-53.3 \%$ & $-14.2 \%$ & $-42.9 \%$ & $-12.6 \%$ & $-32.9 \%$ \\
\hline & $\mathrm{NO}_{2}$ & $-28.0 \%$ & & $-34.1 \%$ & & $-23.9 \%$ & & $-25.3 \%$ & & $-22.1 \%$ & \\
\hline & $\mathrm{PM}_{10}$ & $-19.7 \%$ & & $-23.6 \%$ & & $-11.2 \%$ & & $-10.4 \%$ & & $-9.6 \%$ & \\
\hline & $\mathrm{PM}_{2.5}$ & $-14.7 \%$ & & $8.2 \%$ & & $9.8 \%$ & & $-1.0 \%$ & & $0.6 \%$ & \\
\hline & $\mathrm{O}_{3}$ & $-17.5 \%$ & & $10.7 \%$ & & $19.3 \%$ & & $14.8 \%$ & & $10.7 \%$ & \\
\hline \multirow[t]{4}{*}{ RS } & $\mathrm{CO}$ & $-57.4 \%$ & $-48.8 \%$ & $-53.1 \%$ & $-52.0 \%$ & $-35.1 \%$ & $-45.6 \%$ & $-29.5 \%$ & $-41.1 \%$ & $-25.4 \%$ & $-31.7 \%$ \\
\hline & $\mathrm{NO}_{2}$ & $-36.1 \%$ & & $-2.4 \%$ & & $-9.0 \%$ & & $21.8 \%$ & & $15.4 \%$ & \\
\hline & $\mathrm{PM}_{10}$ & $-1.1 \%$ & & $-7.7 \%$ & & $9.1 \%$ & & $-1.3 \%$ & & $-7.0 \%$ & \\
\hline & $\mathrm{O}_{3}$ & $-37.4 \%$ & & $26.3 \%$ & & $18.5 \%$ & & $22.5 \%$ & & $13.1 \%$ & \\
\hline \multirow[t]{5}{*}{ SP } & $\mathrm{CO}$ & $-37.0 \%$ & $-47.0 \%$ & $-39.5 \%$ & $-51.7 \%$ & $-20.2 \%$ & $-50.6 \%$ & $-16.5 \%$ & $-42.2 \%$ & $-10.9 \%$ & $-32.6 \%$ \\
\hline & $\mathrm{NO}_{2}$ & $-24.2 \%$ & & $-28.8 \%$ & & $-14.5 \%$ & & $-14.9 \%$ & & $-11.4 \%$ & \\
\hline & $\mathrm{PM}_{10}$ & $-10.0 \%$ & & $-13.9 \%$ & & $-1.0 \%$ & & $-3.2 \%$ & & $-0.6 \%$ & \\
\hline & $\mathrm{PM}_{2.5}$ & $-12.3 \%$ & & $-20.4 \%$ & & $-4.5 \%$ & & $-10.4 \%$ & & $-7.1 \%$ & \\
\hline & $\mathrm{O}_{3}$ & $-15.9 \%$ & & $15.4 \%$ & & $20.2 \%$ & & $16.5 \%$ & & $22.2 \%$ & \\
\hline
\end{tabular}

Note: The intervals shown correspond to the number of days counted from $16^{\text {th }}$ March 2020 , and the corresponding period for

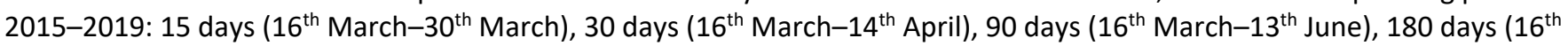
March-11 $11^{\text {th }}$ September) and 290 days (16 ${ }^{\text {th }}$ March-31 $1^{\text {st }}$ December). 
during this period that favored the remotion of air pollutants and their precursors (in the case of secondary pollutants) since $\mathrm{O}_{3}$ precursors (e.g., $\mathrm{NO}_{2}$ ), for example, decreased at the same magnitude observed during the first 30 days.

During the first 30 days, the most significant reductions were observed for $\mathrm{CO}$ (average reduction of $\sim 40 \%$ ) and $\mathrm{NO}_{2}(\sim 20 \%)$, pollutants strongly associated with vehicular emissions (Batterman et al., 2015; Fischer et al., 2000; González et al., 2017). In this case, attention should be given to the reductions in CO concentrations observed for the States of Rio Grande do Sul, Paraná, and São Paulo, which presented reductions of, respectively, 53\% (2015-2019: $208.6 \pm 63.6 \mu \mathrm{g} \mathrm{m}^{-3} ; 2020$ : $\left.114.6 \pm 55.4 \mu \mathrm{g} \mathrm{m}^{-3}\right), 45 \%$ (2015-2019: $\left.890.3 \pm 277.2 \mu \mathrm{g} \mathrm{m}^{-3} ; 2020: 417.3 \pm 56.3 \mu \mathrm{g} \mathrm{m}^{-3}\right)$, and 39\% (2015-2019: $659.7 \pm 45.2 \mu \mathrm{g} \mathrm{m}^{-3}$; 2020: $399.1 \pm 130.6 \mu \mathrm{g} \mathrm{m}^{-3}$ ). Additionally, the substantial increase in $\mathrm{O}_{3}$ concentrations for the same States was also highlighted, which reached $44 \%$ (2015-2019: $18.7 \pm 3.4 \mu \mathrm{g} \mathrm{m}^{-3}$; 2020: $26.9 \pm 5.5 \mu \mathrm{g} \mathrm{m}^{-3}$ ) in Paraná, 26\% (2015-2019: $25.9 \pm$ $3.4 \mu \mathrm{g} \mathrm{m}^{-3} ; 2020: 32.7 \pm 8.1 \mu \mathrm{g} \mathrm{m}^{-3}$ ) in Rio Grande do Sul, and 15\% in São Paulo (2015-2019: 38.3 $\pm 3.9 \mu \mathrm{g} \mathrm{m}^{-3} ; 2020: 44.2 \pm 6.0 \mu \mathrm{g} \mathrm{m}^{-3}$ ).

For more extended periods (from 90 days), less significant reductions are observed for most primary pollutants and analyzed States. On the other hand, an even more notable increase in $\mathrm{O}_{3}$ concentrations was observed for the Spring season, which, together with Summer, are the seasons that are more favorable conditions to the $\mathrm{O}_{3}$ formation (Squizzato et al., 2021). A large part of this reduction kept for longer periods is related to the high decreases observed in the initial mobility restrictions since these days are included in the more extended periods. The increase in pollutants is consistent with increased mobility, which although having different characteristics in the States, show a tendency to increase soon after the initial days of restriction (Fig. 2). During the 90-day period, it is important to mention the increase in PM concentrations, which showed a positive relative difference in the State of Rio Grande do Sul (2015-2019: 20.8 \pm $\left.5.0 \mu \mathrm{g} \mathrm{m}^{-3} ; 2020: 22.7 \pm 10.8 \mu \mathrm{g} \mathrm{m}^{-3}\right)$. This occurred even with a high rate of reduction in mobility observed for the same period in the State $(-45.6 \%)$. This can be explained by the high number of fire outbreaks observed for that period, which reached record levels in Brazil (Pivello et al., 2021), even during the pandemic. The increase in the number of fire outbreaks was observed throughout the entire national territory (Fig. S4), even in floodable biomes where the impact of fires is generally smaller (Pletsch et al., 2021). In the specific case of Rio Grande do Sul, from January to May 2020, the State even presented a fourfold increase in the number of fires outbreaks when compared to 2019, surpassing states such as Mato Grosso (increase of 13\%) and Mato Grosso do Sul (86\%), which are traditionally beset with biomass burning (GZH, 2020). In addition to local fire outbreaks, the region studied is highly impacted by the transport of long-range air masses, which can significantly deteriorate local air quality, even in large urban centers (Lopes et al., 2012; Martins et al., 2018; Rudke et al., 2021; dos Santos, 2011).

\subsection{Spatial Variability of Air Quality Changes}

As mentioned above, the Brazilian federal government has not adopted a national regulation of social isolation aimed at containing the COVID-19 pandemic. Given the inertia of the Federal government, the Brazilian Supreme Court ruled that, in addition to the federal government, state and municipal governments could also determine isolation, quarantine, and mobility restrictions due to the pandemic (STF, 2020). The first restrictions were adopted by the State of São Paulo and followed by Rio de Janeiro, Rio Grande do Sul, and Paraná states (16 ${ }^{\text {th }}$ March 2021). On the $21^{\text {st }}$ of the same month, the State of Espírito Santo also decreed the suspension of their activities.

As decision-making was carried out in particular by municipalities (together with the state level, in most States), different types of restrictions were adopted in Brazil. Thus, when studying the average impacts caused by mobility on air pollution by State, there may be some masking of localized effects due to local political and economic characteristics. For instance, increases in air pollutant concentrations in some Chilean cities were detected, even though the general behavior observed for the country was one of reduction (Morales-Solís et al., 2021). Therefore, increases in air pollutant concentrations in a given city with soft restrictions coupled with reductions seen in other locations can nullify the impact of restrictions at the state level.

When the impact of mobility restrictions is verified by an air quality station (Fig. 3), it is noted that the general trend of variation is maintained for the studied pollutants and States, with reductions for the primary pollutants and increases for $\mathrm{O}_{3}$ (with local variation in intensity). 


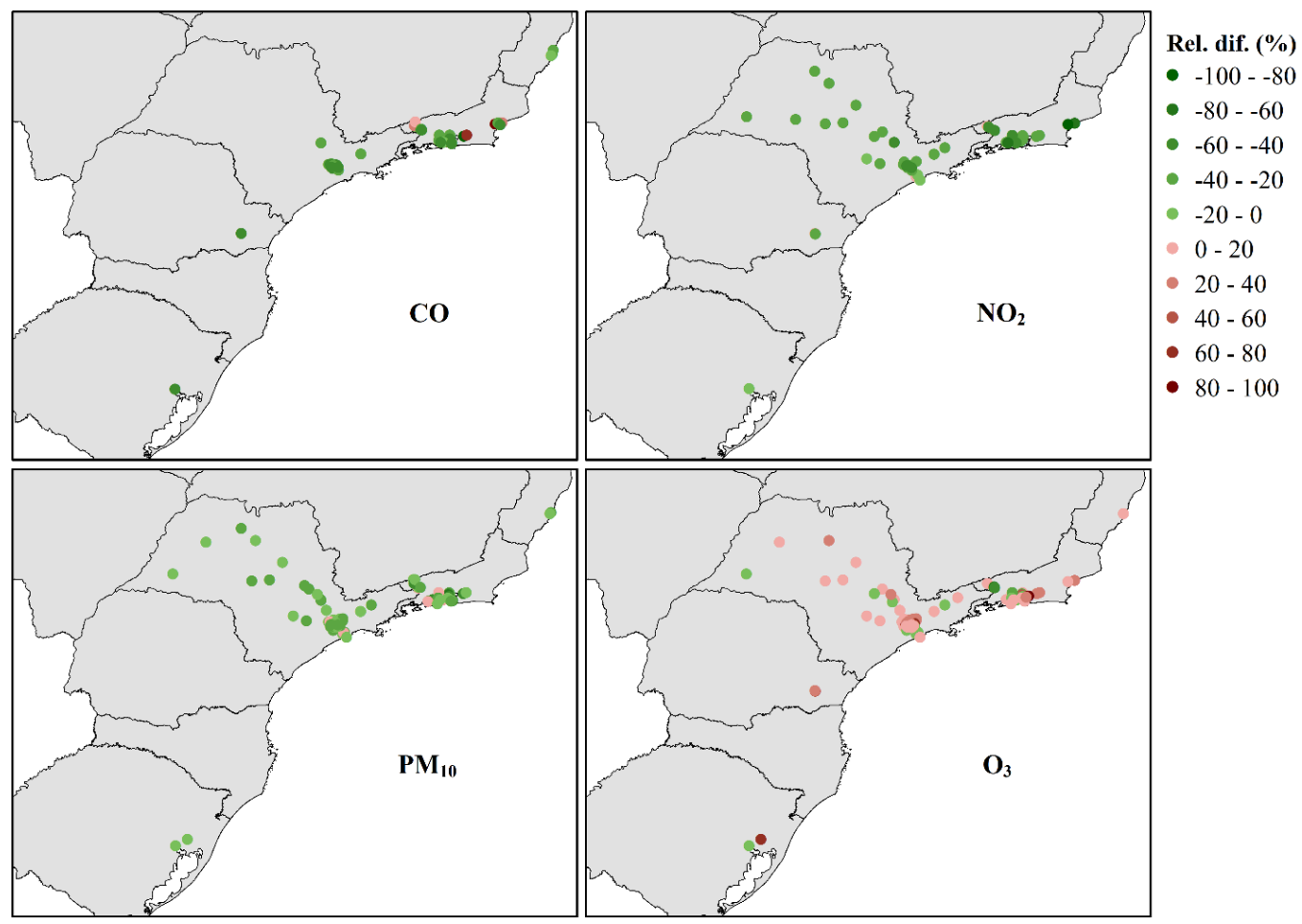

Fig. 3. Air pollutants spatial distribution across the study area and relative difference (\%) between $16^{\text {th }}$ March with the subsequent 30 days for 2019 and 2020.

In Paraná, there was a slight increase in $\mathrm{NO}_{2}$ (2.5\%) for a station located in a residential area and a decrease for another station (-26.7\%). The reduction in $\mathrm{NO}_{2}$ occurred because the station is close to a highway (BR 476); thus with the decrease in mobility, there was also a reduction in the pollutant concentration. For the State of Rio de Janeiro, increases in CO concentrations were observed at some monitoring stations, reaching 70.6\% (2015-2019: $364.7 \mu \mathrm{g} \mathrm{m}^{-3}$; 2020: 622.1 $\mu \mathrm{g} \mathrm{m}^{-3}$ ) for Itb - Sambaetiba station and 94.4\% (2015-2019: 366.4 $\mu \mathrm{g} \mathrm{m}^{-3} ; 2020: 712.3 \mu \mathrm{g} \mathrm{m}^{-3}$ ) for Mc - Fazenda Aires station, which prevented further reductions in pollutant concentrations at the state level. The Itb - Sambaetiba station is located in a sparsely urbanized region, thus suffering less impact from mobility restrictions. Besides, the Mc - Fazenda Aires station is located in a rural area, being more affected by local biomass burning events.

Spatially, the greatest reductions in pollutant concentrations were measured in more densely populated areas (Figs. 1, 3, and 4). The analyzed States comprise the most urbanized and industrialized region in Brazil (IBGE, 2016), containing important metropolitan areas [e.g., Metropolitan Areas of Greater Vitória (MAGV), São Paulo (MASP), Rio de Janeiro (MARJ), Curitiba (MAC) and Porto Alegre (MAPA)], which showed the greatest reductions observed locally (only data from stations located in the metropolitan area considered). For $\mathrm{CO}$, during the first 30 days of mobility restriction, there was a reduction of 43\% (2015-2019: $429.1 \mu_{\mathrm{g} \mathrm{m}^{-3}} ; 2020: 242.8 \mu \mathrm{g} \mathrm{m}^{-3}$ ) for MAPA, 41\% (2015-2019: $102.8 \mu \mathrm{g} \mathrm{m}^{-3}$; 2020: $60.0 \mu \mathrm{g} \mathrm{m}^{-3}$ ) for MAC, 41\% (2015-2019: 279.3 $\mu \mathrm{g} \mathrm{m}^{-3}$; 2020: $165.7 \mu \mathrm{g} \mathrm{m}^{-3}$ ) for MASP, 30\% (2015-2019: $217.0 \mu \mathrm{g} \mathrm{m}^{-3}$; 2020: $151.1 \mu \mathrm{g} \mathrm{m}^{-3}$ ) for MARJ, and 24\% (2015-2019: 348.0 $\mu \mathrm{g} \mathrm{m}^{-3}$; 2020: $263.3 \mu \mathrm{g} \mathrm{m}^{-3}$ ) for MAGV.

For $\mathrm{NO}_{2}$, there was a reduction of 33\% (2015-2019: $\left.10.5 \mu \mathrm{g} \mathrm{m}^{-3} ; 2020: 7.0 \mu \mathrm{g} \mathrm{m}^{-3}\right)$ for MARJ, 32\% (2015-2019: $13.0 \mu \mathrm{g} \mathrm{m}^{-3}$; 2020: $8.8 \mu \mathrm{g} \mathrm{m}^{-3}$ ) for MASP, 14\% (2015-2019: $238 \mu \mathrm{g} \mathrm{m}^{-3}$; 2020: 20.4 $\mu_{\mathrm{g} \mathrm{m}^{-3}}$ ) for MAC, and 8\% (2015-2019: $4.4 \mu \mathrm{g} \mathrm{m}^{-3}$; 2020: $4.0 \mu \mathrm{g} \mathrm{m}^{-3}$ ) for MAPA. The expressive $\mathrm{NO}_{2}$ reductions for MARJ and MASP are also evidenced when evaluating the Tropospheric $\mathrm{NO}_{2}$ density data measured by the TROPOMI sensor (Fig. 4).

As $\mathrm{CO}$ and $\mathrm{NO}_{2}$, similar behavior was observed for $\mathrm{PM}_{10}$ that presented reduction of $27 \%$ (2015-2019: $25.2 \mu \mathrm{g} \mathrm{m}^{-3}$; 2020: $18.5 \mu \mathrm{g} \mathrm{m}^{-3}$ ) for MARJ, 23\% (2015-2019: $14.1 \mu \mathrm{g} \mathrm{m}^{-3}$; 2020: $10.8 \mu \mathrm{g} \mathrm{m}^{-3}$ ) for MAGV, 19\% (2015-2019: $17.9 \mu \mathrm{g} \mathrm{m}^{-3} ; 2020: 14.5 \mu \mathrm{g} \mathrm{m}^{-3}$ ) for MASP, and 10\% (2015-2019: $21.0 \mu \mathrm{g} \mathrm{m}^{-3} ; 2020: 18.8 \mu \mathrm{g} \mathrm{m}^{-3}$ ) for MAPA. On the other hand, there were significant 

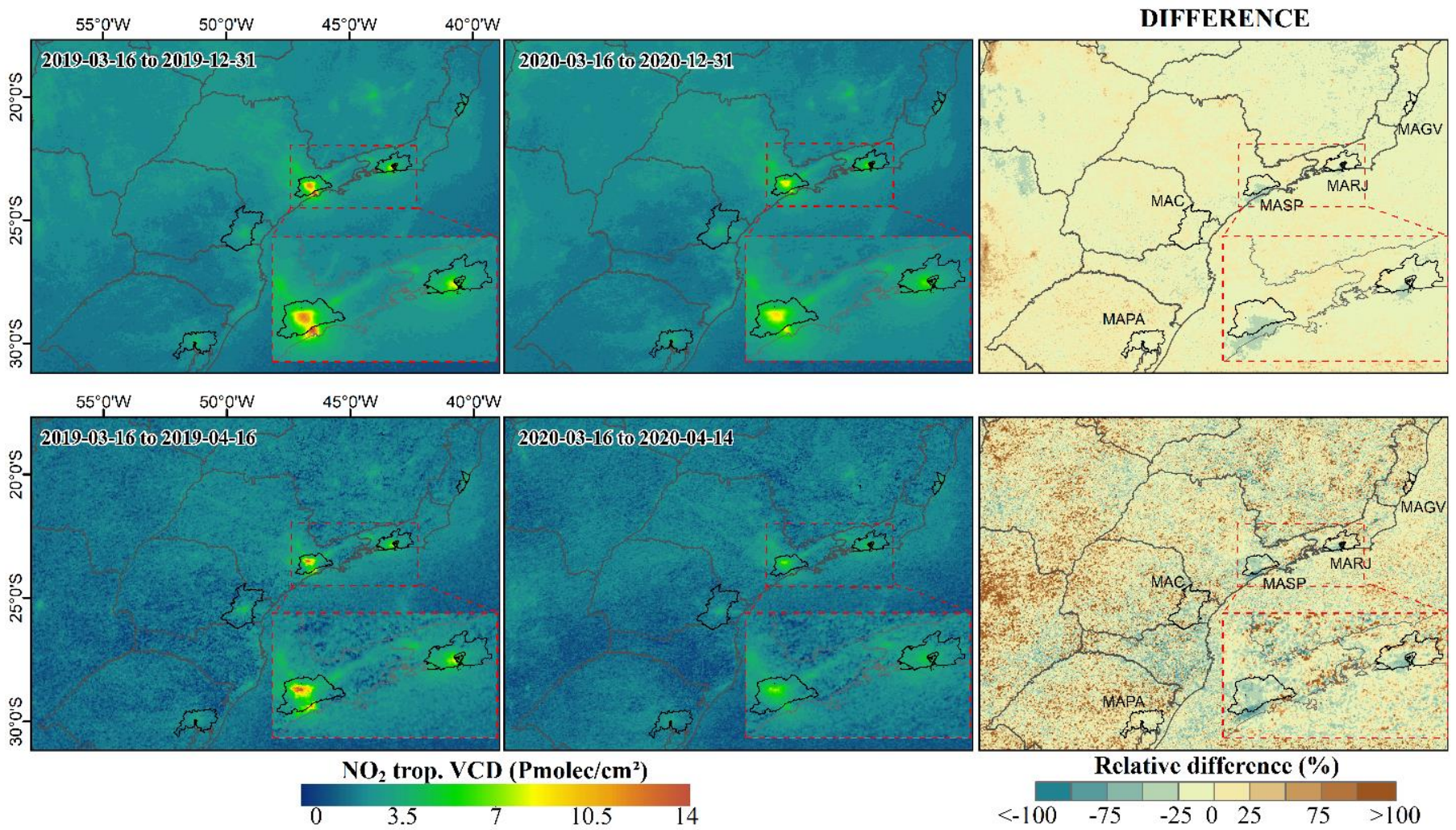

Fig. 4. Mean levels of tropospheric $\mathrm{NO}_{2}$ density measured by TROPOMI sensor and relative difference (\%) for the period from $16^{\text {th }}$ March and the 30 subsequent days for 2019 and 2020. The acronyms presented identify the Metropolitan Areas of Grande Vitória (MAGV), São Paulo (MASP), Rio de Janeiro (MARJ), Curitiba (MAC) and, Porto Alegre (MAPA).

increases in the first 30 days of restriction for $\mathrm{O}_{3}$, which reached $45 \%$ in MAC (2015-2019: 18.6 $\mu \mathrm{g} \mathrm{m}^{-3}$; 2020: $\left.26.6 \mu \mathrm{g} \mathrm{m}^{-3}\right), 36 \%$ in MASP $\left(29.6 \mu \mathrm{g} \mathrm{m}^{-3} ; 2020: 35.6 \mu \mathrm{g} \mathrm{m}^{-3}\right), 26 \%$ in MAPA $\left(25.9 \mu \mathrm{g} \mathrm{m}^{-3} ; 2020: 32.6 \mu \mathrm{g} \mathrm{m}^{-3}\right), 11 \%$ in MARJ $\left(25.5 \mu \mathrm{g} \mathrm{m}^{-3} ; 2020: 28.2 \mu \mathrm{g} \mathrm{m}^{-3}\right)$, and $5 \%$ in MAGV $\left(11.2 \mu \mathrm{g} \mathrm{m}^{-3} ; 2020: 11.7 \mu \mathrm{g} \mathrm{m}^{-3}\right)$.

The results presented here agree with the studies previously carried out for the MASP and MARJ regions (Connerton et al., 2020; Dantas et al., 2020; Debone et al., 2020; Ibarra-Espinosa et al., 2021; Nakada and Urban, 2020; Noda et al., 2021; Rudke et al., 2021; Siciliano et al., 2020a; Tadano et al., 2021), with variations directly related to the study period and how air quality monitoring stations were selected. It should also be noted that even for stations located in the countryside of the States, there is a similar trend in the reduction/increase of air pollutants. This demonstrates the important role of vehicular emission restrictions policies on local/regional air quality, as mobility restrictions carried out mainly in the first 30 days had the potential to affect the average annual concentrations expected for 2020 .

\section{CONCLUSIONS}

The 2020 COVID-19 outbreak deployed a unique opportunity to assess how human activities affect air quality. In this study, we investigated how the restrictive measures imposed in 2020 to reduce the transmission of COVID-19 influenced the air quality of Brazil. Our results demonstrate that, although the federal government had no active participation in developing regulations aimed at social distancing, the Brazilian States used almost the same strategies related to mobility restriction orders. In general, we can affirm that these restrictions adopted by the States had a substantial impact on concentrations of pollutants $\mathrm{CO}, \mathrm{NO}_{2}$ and $\mathrm{PM}_{10}$, and $\mathrm{PM}_{2.5}$, mainly during the first 30 days after the beginning of mobility restriction. The same did not happen with $\mathrm{O}_{3}$, which reached an increase of $44 \%$ in its concentrations at the end of 2020 (Spring and Summer seasons are more favorable to $\mathrm{O}_{3}$ formation), following a global trend observed in previous studies. 
About the spatial analysis, it was possible to demonstrate that in large urban centers, such as the metropolitan areas of the capitals of the five States (MAGV, MASP, MARJ, MAPA, and MAC), they were the ones that showed more effects in the first 30 days of restrictions. A particular emphasis must be given to the MARJ and MASP (largest metropolitan areas in Brazil), which have high vehicle fleet and demonstrated significant reductions in $\mathrm{NO}_{2}$ concentrations, as observed by the TROPOMI sensor.

Finally, we highlight the importance of mitigating and reducing air pollution indices to reach the new guidelines of the World Health Organization to prevent health and economic impacts. We believe that changes, for example, in the work regime and improvements on public transportation could contribute to it as evidence, especially for primary pollutants. We hope this study will provide subsidies for future policies to control these pollutants, especially when all activities return post COVID-19 pandemic.

It is important to mention that as all studies that require large datasets carried out in Brazil, this one also has limitations. The first limitation is related to the availability of the air quality measurements held in the country; Although some States have measurements for 2020, these datasets are not yet available for public access. In addition to this, a large part of the monitoring stations still relies on manual measurements, and to minimize errors, in this study, we chose to use measures from automatic stations, thus limiting the spatial reach of this study. Besides that, considering the Brazilian territorial area, a small amount of air pollution monitoring stations are available in the country [only 0.03 air quality stations per $1,000 \mathrm{~km}^{2}$ (Réquia et al., 2015)]. Our second limitation is related to a lack of clarity in disseminating information about the restrictions policies carried out by the state health departments, as well as a timetable for their implementation. Most of the data used in the discussions were sourced from media news.

\section{ACKNOWLEDGMENTS}

The authors would like to acknowledge the Coordination of Superior Level Staff Improvement (Coordenação de Aperfeiçoamento de Pessoal de Nível Superior), finance Code 001 and process No. 88887505019/2020-00, the National Council for Scientific and Technological Development (Conselho Nacional de Desenvolvimento Científico e Tecnológico - CNPq, process 306862/2018-2). This paper was also supported by grant 068/2019 (Fundação Araucária PI 05/2019 Water JPI) under the International Consortium Research-based Assessment of Integrated approaches to Nature-based SOLUTIONS (RainSolutions) - CONFAP Cooperation Program Water JPI 2018 Joint Call. Finally, the Environmental Agencies to provide the air quality dataset.

\section{DISCLAIMER}

The authors declare that they are not aware of competing for financial interests or personal relationships that could appear to have influenced the work reported in this paper.

\section{SUPPLEMENTARY MATERIAL}

Supplementary material for this article can be found in the online version at https://doi. org/10.4209/aaqr.210351

\section{REFERENCES}

Alfano, V., Ercolano, S. (2020). The efficacy of lockdown against COVID-19: A cross-country panel analysis. Appl. Health Econ. Health Policy 18, 509-517. https://doi.org/10.1007/s40258-02000596-3

Almeida, D.S., da Costa, S.C., Ribeiro, M., Moreira, C.A.B., Beal, A., Squizzato, R., Rudke, A.P., Rafee, S.A.A., Martins, J.A., Palioto, G.F., Kumar, P., Martins, L.D. (2018). Genotoxic effects of daily personal exposure to particle mass and number concentrations on buccal cells. Atmos. Environ. 176, 148-157. https://doi.org/10.1016/j.atmosenv.2017.12.021 
Andrade, F.M., Miranda, R.M., Fornaro, A., Kerr, A., Oyama, B., Andre, P.A., Saldiva, P. (2012). Vehicle emissions and $\mathrm{PM}_{2.5}$ mass concentrations in six Brazilian cities. Air Qual. Atmos. Health 5, 79-88. https://doi.org/10.1007/s11869-010-0104-5

Andrade, M. de F., Kumar, P., de Freitas, E.D., Ynoue, R.Y., Martins, J., Martins, L.D., Nogueira, T., Perez-Martinez, P., de Miranda, R.M., Albuquerque, T., Gonçalves, F.L.T., Oyama, B., Zhang, Y. (2017). Air quality in the megacity of São Paulo: Evolution over the last 30 years and future perspectives. Atmos. Environ. 159, 66-82. https://doi.org/10.1016/j.atmosenv.2017.03.051

Bainy, B.K., Paschoal, I.A., de Avila, A.M.H., dos Santos, H.O. (2021). Air quality assessment in Southeast Brazil during COVID-19 pandemic and lockdown: report of increased air pollution. Cad. Saúde Pública 37, e00242320. https://doi.org/10.1590/0102-311x00242320

Bao, R., Zhang, A. (2020). Does lockdown reduce air pollution? Evidence from 44 cities in northern China. Sci. Total Environ. 731, 139052. https://doi.org/10.1016/j.scitotenv.2020.139052

Bassani, C., Vichi, F., Esposito, G., Montagnoli, M., Giusto, M., lanniello, A. (2021). Nitrogen dioxide reductions from satellite and surface observations during COVID-19 mitigation in Rome (Italy). Environ. Sci. Pollut. Res. 28, 22981-23004. https://doi.org/10.1007/s11356-020-12141-9

Batterman, S., Ganguly, R., Harbin, P. (2015). High resolution spatial and temporal mapping of traffic-related air pollutants. Int. J. Environ. Res. Public Health 12, 3646-3666. https://doi.org/ 10.3390/ijerph120403646

Bauwens, M., Compernolle, S., Stavrakou, T., Müller, J.F., Gent, J., Eskes, H., Levelt, P.F., van der A, R., Veefkind, J.P., Vlietinck, J., Yu, H., Zehner, C. (2020). Impact of coronavirus outbreak on $\mathrm{NO}_{2}$ pollution assessed using TROPOMI and OMI observations. Geophys. Res. Lett. 47, e2020GL087978. https://doi.org/10.1029/2020GL087978

Blumenthal, D., Fowler, E.J., Abrams, M., Collins, S.R. (2020). Covid-19 - Implications for the health care system. N. Engl. J. Med. 383, 1483-1488. https://doi.org/10.1056/NEJMsb2021088

Brito, J., Carbone, S., Monteiro Dos Santos, D.A., Dominutti, P., De Oliveira Alves, N., Rizzo, L., Artaxo, P. (2018). Disentangling vehicular emission impact on urban air pollution using ethanol as a tracer. Sci. Rep. 8, 10679. https://doi.org/10.1038/s41598-018-29138-7

Carvalho, V.S.B., Freitas, E.D., Martins, L.D., Martins, J.A., Mazzoli, C.R., Andrade, M. de F. (2015). Air quality status and trends over the Metropolitan Area of São Paulo, Brazil as a result of emission control policies. Environ. Sci. Policy 47, 68-79. https://doi.org/10.1016/j.envsci. 2014.11.001

Cersosimo, A., Serio, C., Masiello, G. (2020). TROPOMI NO 2 tropospheric column data: Regridding to $1 \mathrm{~km}$ grid-resolution and assessment of their consistency with in situ surface observations. Remote Sens. 12, 2212. https://doi.org/10.3390/rs12142212

Chossière, G.P., Xu, H., Dixit, Y., Isaacs, S., Eastham, S.D., Allroggen, F., Speth, R.L., Barrett, S.R.H. (2021). Air pollution impacts of COVID-19-related containment measures. Sci. Adv. 7, eabe1178. https://doi.org/10.1126/sciadv.abe1178

Collivignarelli, M.C., Abbà, A., Bertanza, G., Pedrazzani, R., Ricciardi, P., Carnevale Miino, M. (2020). Lockdown for CoViD-2019 in Milan: What are the effects on air quality? Sci. Total Environ. 732, 139280. https://doi.org/10.1016/j.scitotenv.2020.139280

Connerton, P., Vicente de Assunção, J., Maura de Miranda, R., Dorothée Slovic, A., José PérezMartínez, P., Ribeiro, H. (2020). Air quality during COVID-19 in four megacities: Lessons and challenges for public health. Int. J. Environ. Res. Public Health 17, 5067. https://doi.org/ 10.3390/ijerph17145067

Conticini, E., Frediani, B., Caro, D. (2020). Can atmospheric pollution be considered a co-factor in extremely high level of SARS-CoV-2 lethality in Northern Italy? Environ. Pollut. 261, 114465. https://doi.org/10.1016/j.envpol.2020.114465

Dantas, G., Siciliano, B., França, B.B., da Silva, C.M., Arbilla, G. (2020). The impact of COVID-19 partial lockdown on the air quality of the city of Rio de Janeiro, Brazil. Sci. Total Environ. 729, 139085. https://doi.org/10.1016/j.scitotenv.2020.139085

de Oliveira Andrade, R. (2020). Covid-19 is causing the collapse of Brazil's national health service. BMJ 368, m3032. https://doi.org/10.1136/bmj.m3032

Debone, D., da Costa, M. V., Miraglia, S.G.E.K. (2020). 90 days of COVID-19 social distancing and its impacts on air quality and health in Sao Paulo, Brazil. Sustainability 12, 7440. https://doi.org/10.3390/su12187440

DENATRAN (2020). Frota de Veículos - Infraestrutura. frota nacional (June 2020). 
dos Santos, N.A.P. (2011). Avaliação do desempenho de produtos químicos na coagulação da água produzida na eta do Aeroporto Internacional do Rio de Janeiro com vistas à redução dos seus custos. Universidade Federal do Rio de Janeiro, Rio de Janeiro - RJ.

Dutheil, F., Baker, J.S., Navel, V. (2020). COVID-19 as a factor influencing air pollution? Environ. Pollut. 263, 2019-2021. https://doi.org/10.1016/j.envpol.2020.114466

Dutta, A., Jinsart, W. (2021). Air quality, atmospheric variables and spread of covid-19 in Delhi (India): An analysis. Aerosol Air Qual. Res. 21, 200417. https://doi.org/10.4209/aaqr.2020. 07.0417

Eskes, H., Van Geffen, J., Boersma, F., Eichmann, K.U., Apituley, A., Pedergnana, M., Sneep, M., Veefkind, J.P., Loyola, D. (2019). Sentinel-5 precursor/TROPOMI Level 2 Product User Manual Nitrogendioxide.

Fan, C., Li, Y., Guang, J., Li, Z., Elnashar, A., Allam, M., de Leeuw, G. (2020). The impact of the control measures during the COVID-19 outbreak on air pollution in China. Remote Sens. 12, 1613. https://doi.org/10.3390/rs12101613

Figueiredo Filho, D.B., de Oliveira Silva, L.E. (2021). Social distancing and severe acute respiratory syndrome coronavirus 2 transmission: A case study from araraquara, São Paulo, Brazil. Rev. Soc. Bras. Med. Trop. 54, e0197-2021. https://doi.org/10.1590/0037-8682-0197-2021

Fischer, P.H., Hoek, G., Van Reeuwijk, H., Briggs, D.J., Lebret, E., Van Wijnen, J.H., Kingham, S., Elliott, P.E. (2000). Traffic-related differences in outdoor and indoor concentrations of particles and volatile organic compounds in Amsterdam. Atmos. Environ. 34, 3713-3722. https://doi.org/ 10.1016/S1352-2310(00)00067-4

Francisco, B.S., Bueno Dutra, F.B., Carvalho-Batista, A., Francisco, F.G.P., Ghidini, M.S., De Souza Cardoso, R., Perussi, G., Soraya de Almeida, L., Santana da Silva, J.M., Conceição Márquez Piña Rodrigues, F. (2021). Social isolation measures cause reduction in the contamination and deaths by Covid-19? the case of the municipality of Araraquara, Sp, Brazil. Interfaces Científicas - Saúde e Ambient. 8, 233-249. https://doi.org/10.17564/2316-3798.2021v8n3p233-249

Gao, H., Wang, J., Li, T., Fang, C. (2021). Analysis of air quality changes and influencing factors in changchun during the COVID-19 pandemic in 2020. Aerosol Air Qual. Res. 21, 210055. https://doi.org/10.4209/aaqr.210055

Geraldi, M.S., Bavaresco, M. V, Triana, M.A., Melo, A.P., Lamberts, R. (2021). Addressing the impact of COVID-19 lockdown on energy use in municipal buildings: A case study in Florianópolis, Brazil. Sustain. Cities Soc. 69, 102823. https://doi.org/10.1016/j.scs.2021.102823

González, C.M., Gómez, C.D., Rojas, N.Y., Acevedo, H., Aristizábal, B.H. (2017). Relative impact of on-road vehicular and point-source industrial emissions of air pollutants in a medium-sized Andean city. Atmos. Environ. 152, 279-289. https://doi.org/10.1016/j.atmosenv.2016.12.048

Grange, S.K., Lee, J.D., Drysdale, W.S., Lewis, A.C., Hueglin, C., Emmenegger, L., Carslaw, D.C. (2021). COVID-19 lockdowns highlight a risk of increasing ozone pollution in European urban areas. Atmos. Chem. Phys. 21, 4169-4185. https://doi.org/10.5194/acp-21-4169-2021

GZH, A. (2020). Queimadas aumentaram quatro vezes no Rio Grande do Sul em 2020.

He, Q., Wang, M., Yim, S.H.L. (2021). The spatiotemporal relationship between PM $_{2.5}$ and aerosol optical depth in China: Influencing factors and implications for satellite $\mathrm{PM}_{2.5}$ estimations using MAIAC aerosol optical depth. Atmos. Chem. Phys. 21, 18375-18391. https://doi.org/10.5194/ acp-21-18375-2021

Hersbach, H., Bell, B., Berrisford, P., Hirahara, S., Horányi, A., Muñoz-Sabater, J., Nicolas, J., Peubey, C., Radu, R., Schepers, D., Simmons, A., Soci, C., Abdalla, S., Abellan, X., Balsamo, G., Bechtold, P., Biavati, G., Bidlot, J., Bonavita, M., Chiara, G., et al. (2020). The ERA5 global reanalysis. Q.J.R. Meteorol. Soc. 146, 1999-2049. https://doi.org/10.1002/qj.3803

Ibarra-Espinosa, S., Dias de Freitas, E., Ropkins, K., Dominici, F., Rehbein, A. (2022). NegativeBinomial and quasi-poisson regressions between COVID-19, mobility and environment in São Paulo, Brazil. Environ. Res. 204, 112369. https://doi.org/10.1016/j.envres.2021.112369

Instituto Brasileiro de Geografia e Estatística (IBGE) (2016). Dados financeiros de empresas de serviços, 2016. Sala de imprensa: Pesquisa Anual de Serviços - PAS. https://www.ibge.gov.br/ estatisticas-novoportal/economicas/servicos/9028-pesquisa-anual-de-servicos.html?=\&t=des taques (accessed 20 October 2018).

Instituto Brasileiro de Geografia e Estatística (IBGE) (2020). Anuário Estatístico do Brasil. Instituto Brasileiro de Geografia e Estatística (IBGE) (2021). Censo demográfico. 
Kawashima, A.B., Martins, L.D., Rafee, S.A.A., Rudke, A.P., de Morais, M.V., Martins, J.A. (2020). Development of a spatialized atmospheric emission inventory for the main industrial sources in Brazil. Environ. Sci. Pollut. Res. 27, 35941-35951. https://doi.org/10.1007/s11356-020-08281-7

Kim, M., Brunner, D., Kuhlmann, G. (2021). Importance of satellite observations for highresolution mapping of near-surface $\mathrm{NO}_{2}$ by machine learning. Remote Sens. Environ. 264, 112573. https://doi.org/10.1016/j.rse.2021.112573

Lau, H., Khosrawipour, V., Kocbach, P., Mikolajczyk, A., Schubert, J., Bania, J., Khosrawipour, T. (2021). The positive impact of lockdown in Wuhan on containing the COVID-19 outbreak in China. J. Travel Med. 27, taaa037. https://doi.org/10.1093/JTM/TAAA037

Liu, L., Zhang, J., Du, R., Teng, X., Hu, R., Yuan, Q., Tang, S., Ren, C., Huang, X., Xu, L., Zhang, Y., Zhang, X., Song, C., Liu, B., Lu, G., Shi, Z., Li, W. (2021). Chemistry of atmospheric fine particles during the COVID-19 pandemic in a megacity of eastern China. Geophys. Res. Lett. 48, 2020GL091611. https://doi.org/10.1029/2020GL091611

Lokhandwala, S., Gautam, P. (2020). Indirect impact of COVID-19 on environment: A brief study in Indian context. Environ. Res. 188, 109807. https://doi.org/10.1016/j.envres.2020.109807

Lopes, F.J.S., Mariano, G.L., Landulfo, E., Mariano, E.V.C. (2012). Impacts of biomass burning in the atmosphere of the southeastern region of Brazil using remote sensing systems, in: AbdulRazzak, H. (Ed.), Atmospheric Aerosols - Regional Characteristics - Chemistry and Physics, InTech. https://doi.org/10.5772/50406

Lu, Z., Noonan, D., Crittenden, J., Jeong, H., Wang, D. (2013). Use of impact fees to incentivize low-impact development and promote compact growth. Environ. Sci. Technol. 47, 1074410752. https://doi.org/10.1021/es304924w

Malta, M., Vettore, M.V., da Silva, C.M.F.P., Silva, A.B., Strathdee, S.A. (2021). Political neglect of COVID-19 and the public health consequences in Brazil: The high costs of science denial. EClinicalMedicine 35, 100878. https://doi.org/10.1016/j.eclinm.2021.100878

Mantovani, I.S., Pimenta, A.F., Bieleski, I.C., Beal, A., Martins, L.D., Solci, M.C. (2021). O impacto de medidas restritivas devido à pandemia por COVID-19 nas concentrações de poluentes atmosféricos em cidade de médio porte. Conjecturas 21, 54-69. https://doi.org/10.53660/ conj-294-316

Martins, L.D., da Silva, I., Batista, W.V., Andrade, M. de F., Freitas, E.D. de, Martins, J.A. (2020). How socio-economic and atmospheric variables impact COVID-19 and influenza outbreaks in tropical and subtropical regions of Brazil. Environ. Res. 191, 110184. https://doi.org/10.1016/ j.envres.2020.110184

Martins, L.D., Hallak, R., Alves, R.C., de Almeida, D.S., Squizzato, R., Moreira, C.A.B., Beal, A., da Silva, I., Rudke, A., Martins, J.A. (2018). Long-range transport of aerosols from biomass burning over southeastern south America and their implications on air quality. Aerosol Air Qual. Res. 18, 1734-1745. https://doi.org/10.4209/aaqr.2017.11.0545

Meo, S.A., Abukhalaf, A.A., Alomar, A.A., AlMutairi, F.J., Usmani, A.M., Klonoff, D.C. (2020). Impact of lockdown on COVID-19 prevalence and mortality during 2020 pandemic: Observational analysis of 27 countries. Eur. J. Med. Res. 25, 1-7. https://doi.org/10.1186/s40001-020-00456-9

Mishra, M., Kulshrestha, U.C. (2021). A brief review on changes in air pollution scenario over south asia during COVID-19 lockdown. Aerosol Air Qual. Res. 21, 200541. https://doi.org/ 10.4209/aaqr.200541

Morales-Solís, K., Ahumada, H., Rojas, J.P., Urdanivia, F.R., Catalán, F., Claramunt, T., Toro, R.A., Manzano, C.A., Leiva-Guzmán, M.A. (2021). The effect of COVID-19 lockdowns on the air pollution of urban areas of central and southern Chile. Aerosol Air Qual. Res. 21, 200677. https://doi.org/10.4209/aaqr.200677

Moreira, C.A.B., Squizzato, R., Beal, A., de Almeida, D.S., Rudke, A.P., Ribeiro, M., Andrade, M. de F., Kumar, P., Martins, L.D. (2018). Natural variability in exposure to fine particles and their trace elements during typical workdays in an urban area. Transp. Res. Part D Transp. Environ. 63, 333-346. https://doi.org/10.1016/j.trd.2018.06.010

MS (2022). MINISTÉRIO DA SAÚDE - Corona Vírus Brasil. Governo Federal do Brasil. https://covid.saude.gov.br/ (accessed 31 January 2022).

Nakada, L.Y.K., Urban, R.C. (2020). COVID-19 pandemic: Impacts on the air quality during the partial lockdown in São Paulo state, Brazil. Sci. Total Environ. 730, 139087. https://doi.org/ 10.1016/j.scitotenv.2020.139087 
Nakazato, R.K., Rinaldi, M.C.S., Domingos, M. (2015). Will technological modernization for power generation at an oil refinery diminish the risks from air pollution to the Atlantic Rainforest in Cubatão, SE Brazil? Environ. Pollut. 196, 489-496. https://doi.org/10.1016/j.envpol.2014.05.011

Noda, L., Nóbrega, A.B.E.Q., da Silva Júnior, J.B.M., Schmidlin, F., Labaki, L. (2021). COVID-19: Has social isolation reduced the emission of pollutants in the megacity of São Paulo-Brazil? Environ. Dev. Sustain. 23, 12233-12251. https://doi.org/10.1007/s10668-020-01166-2

Pak, A., Adegboye, O.A., Adekunle, A.I., Rahman, K.M., McBryde, E.S., Eisen, D.P. (2020). Economic consequences of the COVID-19 outbreak: The need for epidemic preparedness. Front. Public Health 8, 241. https://doi.org/10.3389/fpubh.2020.00241

Pivello, V.R., Vieira, I., Christianini, A. V., Ribeiro, D.B., da Silva Menezes, L., Berlinck, C.N., Melo, F.P.L., Marengo, J.A., Tornquist, C.G., Tomas, W.M., Overbeck, G.E. (2021). Understanding Brazil's catastrophic fires: Causes, consequences and policy needed to prevent future tragedies. Perspect. Ecol. Conserv. 19, 233-255. https://doi.org/10.1016/J.PECON.2021.06.005

Pletsch, M.A.J.S., Silva Junior, C.H.L., Penha, T.V., Körting, T.S., Silva, M.E.S., Pereira, G., Anderson, L.O., Aragão, L.E.O.C. (2021). The 2020 Brazilian pantanal fires. An. Acad. Bras. Cienc. 93, 20202022. https://doi.org/10.1590/0001-3765202120210077

Rafee, S.A.A., Martins, L.D., Kawashima, A.B., Almeida, D.S., Morais, M.V.B., Souza, R.V.A., Oliveira, M.B.L., Souza, R.A.F., Medeiros, A.S.S., Urbina, V., Freitas, E.D., Martin, S.T., Martins, J.A. (2017). Contributions of mobile, stationary and biogenic sources to air pollution in the Amazon rainforest: A numerical study with the WRF-Chem model. Atmos. Chem. Phys. 17, 7977-7995. https://doi.org/10.5194/acp-17-7977-2017

Rana, R.H., Keramat, S.A., Gow, J. (2021). A systematic literature review of the impact of COVID19 lockdowns on air quality in China. Aerosol Air Qual. Res. 21, 200614. https://doi.org/ 10.4209/aaqr.200614

Réquia, W.J., Koutrakis, P., Roig, H.L. (2015). Spatial distribution of vehicle emission inventories in the Federal District, Brazil. Atmos. Environ. 112, 32-39. https://doi.org/10.1016/j.atmosenv. 2015.04.029

Rocha, C.A., Marques, E.V, Santos, R.P., De Santiago, Í.S. (2021). A better understanding of air quality resulting from the effects of the 2020 pandemic in a city in the equatorial region (Fortaleza, Brazil). Environ. Sci. Pollut. Res. 29, 20921-20938. https://doi.org/10.1007/s11356-021-16697-y

Rudke, A.P., Martins, J.A., de Almeida, D.S., Martins, L.D., Beal, A., Hallak, R., Freitas, E.D., Andrade, M.F., Foroutan, H., Baek, B.H., de A. Albuquerque, T.T. (2021). How mobility restrictions policy and atmospheric conditions impacted air quality in the State of São Paulo during the COVID-19 outbreak. Environ. Res. 198, 111255. https://doi.org/10.1016/j.envres.2021.111255

Salvo, A., Brito, J., Artaxo, P., Geiger, F.M. (2017). Reduced ultrafine particle levels in São Paulo's atmosphere during shifts from gasoline to ethanol use. Nat. Commun. 8, 77. https://doi.org/ 10.1038/s41467-017-00041-5

Sharma, S., Zhang, M., Anshika, Gao, J., Zhang, H., Kota, S.H. (2020). Effect of restricted emissions during COVID-19 on air quality in India. Sci. Total Environ. 728, 138878. https://doi.org/ 10.1016/j.scitotenv.2020.138878

Sicard, P., De Marco, A., Agathokleous, E., Feng, Z., Xu, X., Paoletti, E., Rodriguez, J.J.D., Calatayud, V. (2020). Amplified ozone pollution in cities during the COVID-19 lockdown. Sci. Total Environ. 735, 139542. https://doi.org/10.1016/j.scitotenv.2020.139542

Siciliano, B., Carvalho, G., da Silva, C.M., Arbilla, G. (2020a). The Impact of COVID-19 Partial Lockdown on Primary Pollutant Concentrations in the Atmosphere of Rio de Janeiro and São Paulo Megacities (Brazil). Bull. Environ. Contam. Toxicol. 105, 2-8. https://doi.org/10.1007/ s00128-020-02907-9

Siciliano, B., Dantas, G., da Silva, C.M., Arbilla, G. (2020b). Increased ozone levels during the COVID-19 lockdown: Analysis for the city of Rio de Janeiro, Brazil. Sci. Total Environ. 737, 139765. https://doi.org/10.1016/j.scitotenv.2020.139765

Silva Júnior, F.M.R., Honscha, L.C., Brum, R.L., Ramires, P.F., Tavella, R.A., Fernandes, C.L.F., Penteado, J.O., Bonifácio, A.S., Volcão, L.M., Santos, M., Coronas, M.V. (2020). Air quality in cities of the extreme south of Brazil. Ecotoxicol. Environ. Contam. 15, 61-67. https://doi.org/ 10.5132/eec.2020.01.08

Souza, C.D.R. de, Silva, S.D., Silva, M.A.V. da, D'Agosto, M. de A., Barboza, A.P. (2013). Inventory of conventional air pollutants emissions from road transportation for the State of Rio de 
Janeiro. Energy Policy 53, 125-135. https://doi.org/10.1016/J.ENPOL.2012.10.021

Squizzato, R., Nogueira, T., Martins, L.D., Martins, J.A., Astolfo, R., Machado, C.B., Andrade, M. de F., Freitas, E.D. de (2021). Beyond megacities: Tracking air pollution from urban areas and biomass burning in Brazil. npj Clim. Atmos. Sci. 4, 17. https://doi.org/10.1038/s41612-02100173-y

STF, S.T.F. (2020). Capítulo 04 - Jurisprudência: ADI 6.341/DF - MEDIDA CAUTELAR NA AÇÃO DIRETA DE INCONSTITUCIONALIDADE 6.341 DISTRITO FEDERAL. Stf.

Tadano, Y.S., Potgieter-Vermaak, S., Kachba, Y.R., Chiroli, D.M.G., Casacio, L., Santos-Silva, J.C., Moreira, C.A.B., Machado, V., Alves, T.A., Siqueira, H., Godoi, R.H.M. (2021). Dynamic model to predict the association between air quality, COVID-19 cases, and level of lockdown. Environ. Pollut. 268, 115920. https://doi.org/10.1016/j.envpol.2020.115920

The Lancet (2020). COVID-19 in Latin America: A humanitarian crisis. Lancet 396, 1463. https://doi.org/10.1016/S0140-6736(20)32328-X

Travaglio, M., Yu, Y., Popovic, R., Selley, L., Leal, N.S., Martins, L.M. (2021). Links between air pollution and COVID-19 in England. Environ. Pollut. 268, 115859. https://doi.org/10.1016/ j.envpol.2020.115859

Tsao, C.C., Campbell, J.E., Mena-Carrasco, M., Spak, S.N., Carmichael, G.R., Chen, Y. (2012). Increased estimates of air-pollution emissions from Brazilian sugar-cane ethanol. Nat. Clim. Change 2, 53-57. https://doi.org/10.1038/nclimate1325

Veefkind, J.P., Aben, I., McMullan, K., Förster, H., de Vries, J., Otter, G., Claas, J., Eskes, H.J., de Haan, J.F., Kleipool, Q., van Weele, M., Hasekamp, O., Hoogeveen, R., Landgraf, J., Snel, R., Tol, P., Ingmann, P., Voors, R., Kruizinga, B., Vink, R., et al. (2012). TROPOMI on the ESA Sentinel-5 Precursor: A GMES mission for global observations of the atmospheric composition for climate, air quality and ozone layer applications. Remote Sens. Environ. 120, 70-83. https://doi.org/ 10.1016/j.rse.2011.09.027

Venter, Z.S., Aunan, K., Chowdhury, S., Lelieveld, J. (2020). COVID-19 lockdowns cause global air pollution declines. Proc. Natl. Acad. Sci. U.S.A. 117, 18984-18990. https://doi.org/10.1073/ pnas. 2006853117

Vieira-Filho, M.S., Lehmann, C., Fornaro, A. (2015). Influence of local sources and topography on air quality and rainwater composition in Cubatão and São Paulo, Brazil. Atmos. Environ. 101, 200-208. https://doi.org/10.1016/j.atmosenv.2014.11.025

Virta, H., Sundström, A.-M., Ialongo, I., Tamminen, J. (2021). Evaluating Satellite Capability in Supporting Traditional Air Quality Monitoring for the Finnish Ministry of the Environment, in: EGU General Assembly 2021, EGU, online, p. undefined. https://doi.org/10.5194/egusphereegu21-7073

Wang, Y., Tian, H., Zhang, L., Zhang, M., Guo, D., Wu, W., Zhang, X., Kan, G.L., Jia, L., Huo, D., Liu, B., Wang, X., Sun, Y., Wang, Q., Yang, P., Maclntyre, C.R. (2020). Reduction of secondary transmission of SARS-CoV-2 in households by face mask use, disinfection and social distancing: a cohort study in Beijing, China. BMJ Glob. Health 5, e002794. https://doi.org/10.1136/bmjgh2020-002794

Wilder-Smith, A., Bar-Yam, Y., Fisher, D. (2021). Lockdown to contain COVID-19 is a window of opportunity to prevent the second wave. J. Travel Med. 27, taaa091. https://doi.org/10.1093/ JTM/TAAA091

Wu, X., Nethery, R.C., Sabath, M.B., Braun, D., Dominici, F. (2020). Exposure to air pollution and COVID-19 mortality in the United States: A nationwide cross-sectional study. medRxiv 2020.04.05.20054502. https://doi.org/10.1101/2020.04.05.20054502

Xu, L., Zhang, J., Sun, X., Xu, S., Shan, M., Yuan, Q., Liu, L., Du, Z., Liu, D., Xu, D., Song, C., Liu, B., Lu, G., Shi, Z., Li, W. (2020). Variation in concentration and sources of black carbon in a megacity of China during the COVID-19 pandemic. Geophys. Res. Lett. 47, e2020GL090444. https://doi.org/10.1029/2020GL090444

Zambrano-Monserrate, M.A., Ruano, M.A., Sanchez-Alcalde, L. (2020). Indirect effects of COVID19 on the environment. Sci. Total Environ. 728, 138813. https://doi.org/10.1016/j.scitotenv. 2020.138813 